\title{
THE ASSESSMENT OF BANDUNG TRIGA REACTOR TANK RADIOACTIVITY USING ORIGEN-2
}

\author{
Sudjatmi K.A., Reinaldy Nazar, K. Kamajaya, P. Ilham Y. \\ Pusat Sains dan Teknologi Nuklir Terapan - Badan Tegaga Nuklir Nasional \\ Jl. Tamansari No. 71 Bandung, 40132 \\ Telp/Fax: 022-2503996/022-2504081 \\ sudjatmi@batan.go.id \\ Diterima: 17-08-2017 \\ Diterima dalam bentuk revisi: 29-09-2017 \\ Disetujui: 06-10-2017
}

\begin{abstract}
THE ASSESSMENT OF BANDUNG TRIGA REACTOR TANK RADIOACTIVITY USING ORIGEN-2. In accordance with the regulation of the Nuclear Energy Regulatory Agency of Indonesia related to the decommissioning of nuclear reactors, the management of the Bandung TRIGA reactor have to prepare a decommissioning plan document of the Bandung TRIGA research reactor. Decommissioning program documents shall be regularly updated every five years of the operation of nuclear reactor. In year 2000, Bandung TRIGA reactor tank have been lined using aluminum alloy 6061-T6 and has activated during reactor operation. The aluminum alloy 6061-T6 contains impurities that can produce high radioactivity and has a long half-life. This paper describes the radioactivity of the reactor tank after activation during the period from 2000 to 2014 using a software ORIGEN-2. Total radioactivity of the reactor tank bottom after decay for 5 years was $1.8310^{-7}$ Curie, while the total radioactivity of reactor tank wall was 3.2 $10^{-3}$ Curie.
\end{abstract}

Keywords: radioactivity, reactor tank, ORIGEN-2, decay.

\section{ABSTRAK}

PERHITUNGAN RADIOAKTIVITAS REAKTOR REAKTOR BANDUNG TRIGA MENGGUNAKAN ORIGEN-2 Sesuai dengan peraturan Badan Pengawas Tenaga Nuklir (BAPETEN) terkait dengan dekomisioning reaktor nuklir, pengelola reaktor TRIGA Bandung harus menyiapkan dokumen program dekomisioning reaktor riset TRIGA Bandung. Dokumen program dekomisioning harus dimutakhirkan secara berkala setiap lima tahun pengoperasian reaktor nuklir. Pada tahun 2000, tangki reaktor TRIGA Bandung telah dilapisi dengan paduan aluminium 6061-T6 dan telah teraktivasi selama operasi reaktor. Paduan aluminium 6061-T6 mengandung kotoran yang bisa menghasilkan radioaktivitas tinggi dan mempunyai waktu paruh yang panjang. Makalah ini menjelaskan tentang radioaktivitas tangki reaktor setelah teraktivasi selama periode 2000 sampai 2014 dengan menggunakan perangkat lunak ORIGEN-2. Total radioaktivitas pada dasar tangki reaktor setelah peluruhan selama 5 tahun adalah 1,83 10 Curie, sedangkan radioaktivitas total dinding tangki reaktor adalah $3,210^{-3}$ Curie..

Kata kunci: radioaktivitas, tangki reaktor, ORIGEN-2, peluruhan.

\section{INTRODUCTION}

A nuclear reactor decommissioning program documents should be prepared during the construction of nuclear reactors.
Review and updating of the decommissioning program document should to be done regularly every five years during the operational phase (1). As data 
supplement of the decommissioning program document, it is necessary to do calculate the radioactivity of reactor components, including the reactor tank. In 2000, Bandung TRIGA reactor power had been increased to 2000 MW. Bandung TRIGA reactor tank composed of two layers. The outside tank is an old tank, while the new tank as a lining as old reactor tank. Old reactor tank has a $199 \mathrm{~cm}$ in diameter and a depth of $625 \mathrm{~cm}$, but the new reactor tank has a diameter of $1 \mathrm{~cm}$ smaller than the old tank and $100 \mathrm{~cm}$ higher. This tank is made of aluminum alloy 6061-T6 type with a thickness of $0.625 \mathrm{~cm}$ (2).

Activation products, i.e. radionuclides, are resulted from the interaction of neutrons with inactive coolant, moderator and structural materials nuclides of the reactor. Most types are occurring through nuclear reactions $(n, y),(n, 2 n),(n, p)$ and $(n, \alpha)$. Activation products are then converted to stabile nuclides by beta transformation which is often accompanied by a gamma radiation (3).

Many people tried to estimate the radionuclide of the reactor component using computer code ORIGEN-2. Mulyono et al has estimated the radionuclide on Triga Mark II research reactor component, specially graphite reflector using computer code ORIGEN-2 (4). Likewise Antti Raty used ORIGEN to calculate the FIR 1 TRIGA activity inventories for decommissioning planning (5).

The primary function of ORIGEN code is to compute time-dependent concentrations and source terms of many nuclides that are simultaneously generated or depleted through neutronic transmutation, fission, radioactive decay, input feed rates, and physical or chemical removal rates. So activation calculations were performed with ORIGEN code using the following parameters as input: space-energy distribution of the neutron flux, nuclear and decay data, material composition (impurities), and the history of operation (6-8). ORIGEN-2 is a revised version of ORIGEN and incorporates updates of the reactor models, cross-sections, fission products yields, decays data and decay photon data, as well as the source code (9). Edi Triyono B.S. et al used ORIGEN-2 for Computational analysis of minor actinide waste transmutation on Kartini reactor (10). R.G. Abrefah et al, used ORIGEN-2 for fuel depletion studies of Ghana Research Reactor (11), while Gabriele Hampel et.al. used ORIGEN -2 for calculating the activity after irradiation and determination of photon sources (12).

This paper presented the results of the calculation of the TRIGA 2000 reactor tank radioactivity after activated by the operation of the reactor from year 2000 to 2014 and the decay time up to 5 years. The reactor tank radioactivity were calculated using ORIGEN-2 software. The neutron flux data which is used as input radioactivity reactor tank calculation, based on the calculation of neutron flux distribution using MCNP software, which is already done by Sudjatmi K.A. et al (13). In this calculation the reactor tank is divided into several areas. The base of the reactor tank is divided into five areas, while the walls of the tank is divided into 11 
areas. It is assumed that the neutron flux in each area is equal.

\section{THEORY}

ORIGEN-2 is a versatile point and decay computer code for use in simulating nuclear fuel cycles and calculating the nuclide compositions of materials contained therein.

Mathematical methods used in ORIGEN-2 are fundamentally the same as those used in ORIGEN (14).

$$
\begin{aligned}
& \frac{d X_{i}}{d t}=\sum_{j=1}^{N} l_{i j} \lambda_{j} X_{j}+\phi \sum_{k=1}^{N} f_{i k} \sigma_{k} X_{k}- \\
& \left(\lambda_{i}+\phi \sigma_{i}\right) X_{i}
\end{aligned}
$$

where:

$$
\begin{aligned}
& X_{\tilde{i}}=\text { atom density of nuclide } \mathrm{i} \\
& N=\text { number of nuclides } \\
& l_{i j}=\text { fractions of radioactive } \\
& \text { disintegration by other } \\
& \text { nuclides, which lead to the } \\
& \text { formation of species } i \\
& \lambda_{i}=\text { radioactive decay constant } \\
& \text { for nuclide i } \\
& \phi \text { = position and energy- } \\
& \text { averaged neutron flux } \\
& f_{i k}=\text { fraction of neutron } \\
& \text { absorption by other } \\
& \text { nuclides which lead to the } \\
& \text { formation of nuclide } i \\
& \sigma_{i}=\text { is the spectrum-averaged } \\
& \text { neutron absorption cross } \\
& \text { section of nuclide } \mathrm{i}
\end{aligned}
$$

Eq. (1) is a homogeneous set of simultaneous first-order ordinary differential equations with constant coefficients, which may be written in matrix notation as

$$
\dot{X}=A X
$$

where:

$\dot{X}=$ time derivative of the nuclide concentrations

$A=$ transition matrix

$X=$ nuclide concentrations

Equation (2) has the known solution:

$$
X(t)=\exp (A t) X(0)
$$

where:

$$
\begin{aligned}
\mathrm{X}(\mathrm{t})= & \begin{array}{l}
\text { concentration of each } \\
\text { nuclide at time } \mathrm{t}
\end{array} \\
\mathrm{X}(0)= & \text { vector of initial nuclide } \\
& \text { concentration } \\
\mathrm{t}= & \text { time at end of time step }
\end{aligned}
$$

The decay data base is required for all ORIGEN-2 calculations. It supplies the following information:

1. the list of nuclides to be considered.

2. the decay half-life and the decay branching fractions for beta (negatron) decay to ground and excited states, positron plus electron capture decay to ground and excited states, internal transitions, alpha decay, spontaneous fission decay, and delayed neutron (beta plus neutron) decay.

3. the recoverable heat per decay for each radioactive parent.

4. the isotopic compositions of naturally occurring elements. 
5. the radionuclide maximum permissible concentration (MPC) values.

Reactor tank radioactivity calculation using the ORIGEN-2 software requires neutron flux, the material composition of the reactor tank and the reactor operating history as input data.

Neutron flux distribution calculation is done using the MCNP code by Sudjatmi et al (13). The neutron flux at the bottom of the TRIGA 2000 Bandung reactor tank can be seen in Figure 1, whereas the neutron flux at the wall of the TRIGA 2000 reactor tank can be seen in Figure 2 (13).

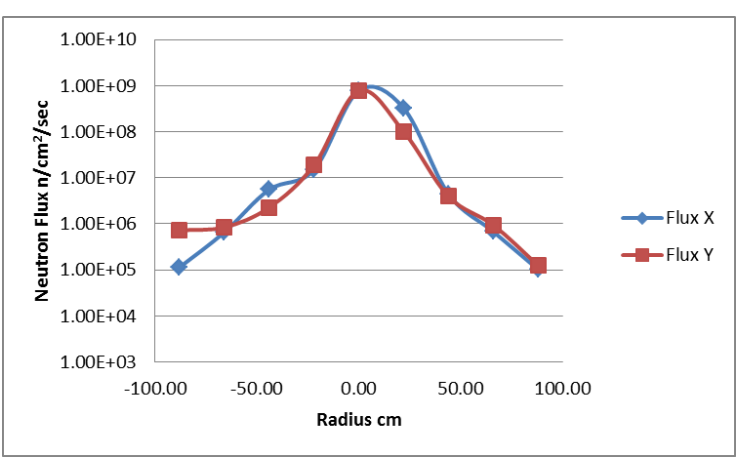

Figure 1. Flux neutron at the bottom of the TRIGA 2000 Bandung reactor tank.

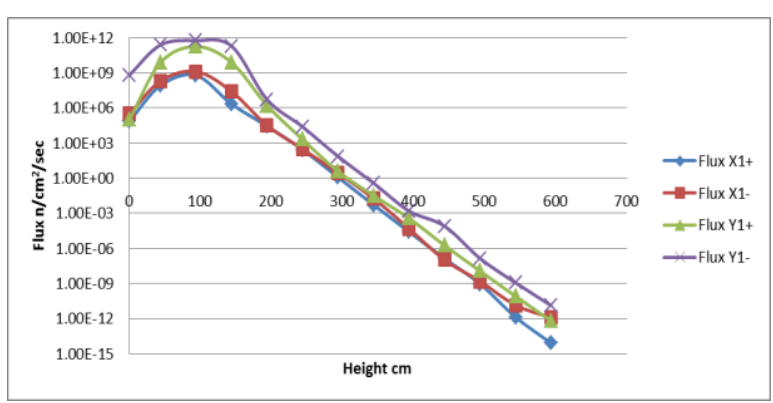

Figure 2. Neutron flux at the TRIGA 2000 Bandung reactor tank wall.

\section{EXPERIMENTAL METHOD}

Bandung TRIGA reactor tank made of anodized 6061-T6 aluminum alloy with thickness of $6.25 \mathrm{~mm}$ (2). The composition of 6061-T6 aluminum alloy can be seen in Table 1.

Table 1.6061-T6 Aluminum composition

\begin{tabular}{lll}
\hline No. & Component & Wt. \% \\
\hline 1 & $\mathrm{Al}$ & \\
2 & $\mathrm{Si}$ & $0.4-0.8$ \\
3 & $\mathrm{Fe}$ & 0.7 \\
4 & $\mathrm{Cu}$ & $0.15-0.40$ \\
5 & $\mathrm{Mn}$ & 0.15 \\
6 & $\mathrm{Mg}$ & $0.8-1.2$ \\
7 & $\mathrm{Cr}$ & $0.04-0.35$ \\
8 & $\mathrm{Zn}$ & 0.25 \\
9 & $\mathrm{Ti}$ & 0.15 \\
10 & Other, total & 0.15 \\
\hline
\end{tabular}

Referring to the distribution of neutron flux as shown in Figure 1 and Figure 2, the reactor tank radioactivity calculations are also carried out separately between the calculation of the bottom of the reactor tank with the calculation of the reactor tank wall. Then the base of the reactor tank was divided into 5 areas and the wall of the reactor tank was divided into 11 areas as shown in Figure 3. The flux of neutrons in each section is assumed to be homogeneous. The tank diameter is $198 \mathrm{~cm}$ and height was $725 \mathrm{~cm}$. 

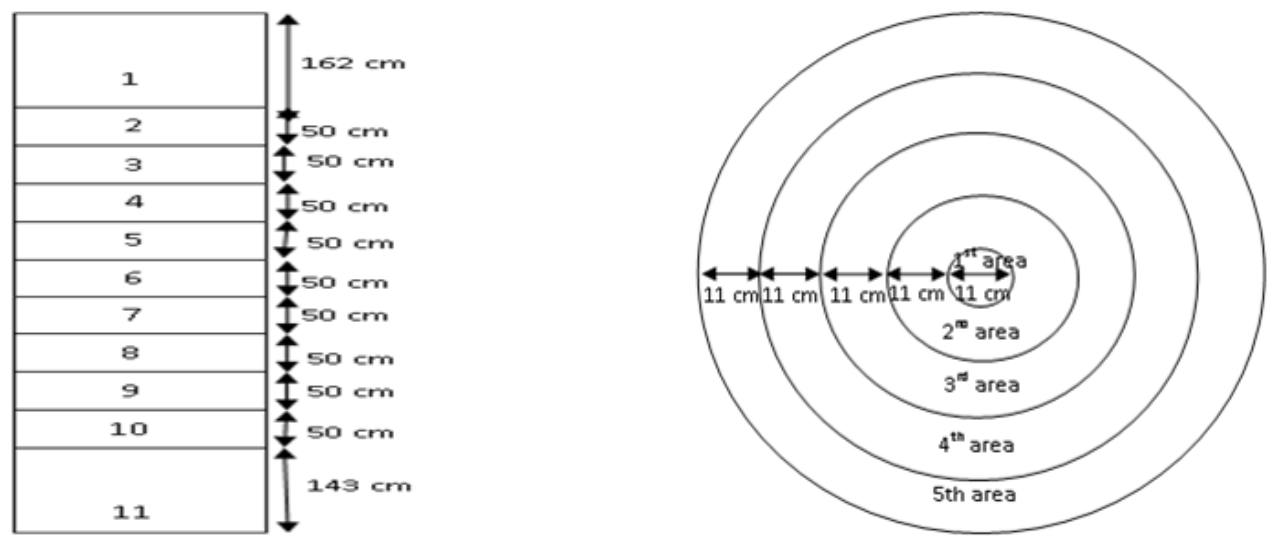

Figure 3. The bottom and walls of the reactor Tank.

\section{RESULTS AND DISCUSSION}

The radioactivity calculation result of the base of reactor tank during the Bandung TRIGA reactor operation period from the year 2000 to 2014 and the decay time up to 5 years using software ORIGEN2 can be seen in Figure 4 and Figure 6. Figure 7 and Figure 8 were the result of the radioactivity calculation of the reactor tank wall.

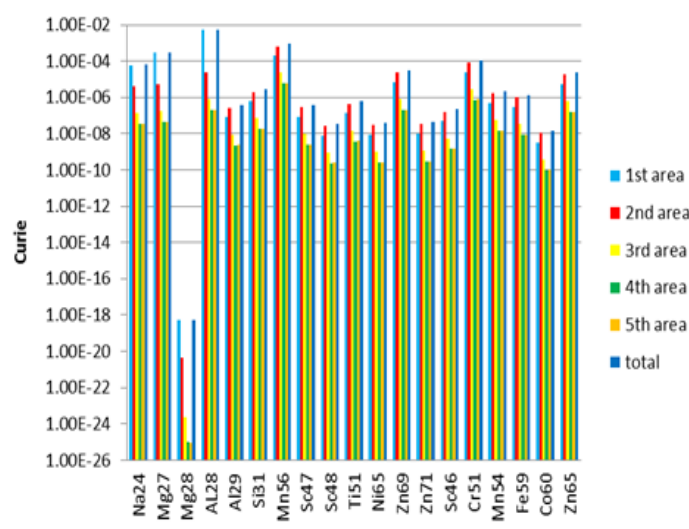

Figure 4. Radioactvity of the bottom of the reactor tank before decay.

Figure 4 shows the bottom of reactor tank radioactivity immediately after the reactor shutdown, before decay. Total radioactivity is $7.210^{-3}$ Curie, that come from
Na24, Mg27, Mg28, Al28, Al29, Si31, Sc47, Sc48, Ti51, Zn69, Zn71, Ni65, Mn56, Cr51, Fe59, Zn65, Co60, Sc46 and Mn54. The highest radioactivity is generated by $\mathrm{Al}$ 28 that is equal to $5.7510^{-3}$ Curie. The halflife of these nuclides can be seen in Table 1.

Table 2. Half-life of Radionuclide (15)

\begin{tabular}{llll}
\hline $\begin{array}{l}\text { Radio- } \\
\text { nuclide }\end{array}$ & Half life & $\begin{array}{l}\text { Radio- } \\
\text { nuclide }\end{array}$ & Half life \\
\hline Na-24 & $14.9 \mathrm{~h}$ & Cr-51 & $27.704 \mathrm{~d}$ \\
Mg-27 & $9.462 \mathrm{~m}$ & $\mathrm{Mn}-54$ & $312.2 \mathrm{~d}$ \\
Mg-28 & $20.9 \mathrm{~h}$ & $\mathrm{Mn}-56$ & $2.5785 \mathrm{~h}$ \\
Al-28 & $2.2406 \mathrm{~m}$ & Fe-59 & $44.496 \mathrm{~d}$ \\
Al-29 & $6.56 \mathrm{~m}$ & Co-60 & $5.271 \mathrm{y}$ \\
Si-31 & $2.622 \mathrm{~h}$ & Ni-65 & $2.52 \mathrm{~h}$ \\
Sc-46 & $83.83 \mathrm{~d}$ & Zn-65 & $244.1 \mathrm{~d}$ \\
Sc-47 & $3.341 \mathrm{~d}$ & Zn-69 & $12.76 \mathrm{~h}$ \\
Sc-48 & $1.821 \mathrm{~d}$ & Zn-71 & $2.45 \mathrm{~m}$ \\
Ti-51 & $5.76 \mathrm{~m}$ & & \\
\hline
\end{tabular}

Because of some radionuclides have a short half-life as listed in Table 2, then in the first year after decay process some radionuclides activities can be ignored, the remaining were Cr51, Fe59, Zn65, Co60, Sc46 and Mn54. 
In Figure 5, it can be seen the radioactivity of Cr51, Fe59, Zn65, Co60, Sc46 and Mn54 in the decay time for the 0, $1^{\text {st }}, 2^{\text {nd }}, 3^{\text {th }}$ and $5^{\text {th }}$ years. Activity of Cr51 in the 5th year has been very little that is of the order of $10^{-23}$ Curie, while activity Zn65, Co60 and Mn54 are still in the order of $10^{-8}$ Curie. It can be seen that the radioactivity decay of Co60 is very small, according to the half-life that is 5.271 year.

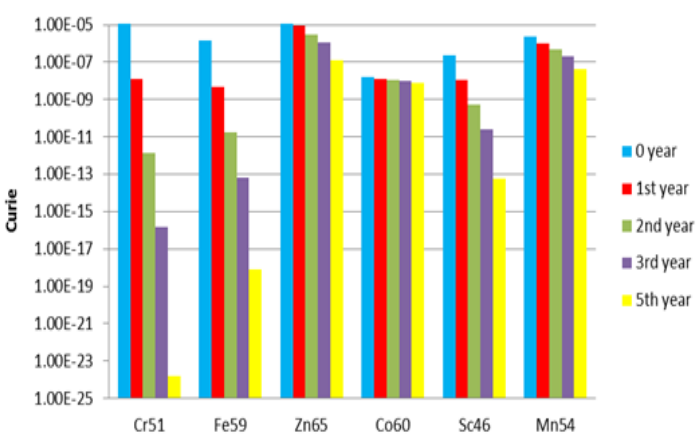

Figure 5. Radionuclide activity on the bottom of the reactor tank in decay period up to 5 years.

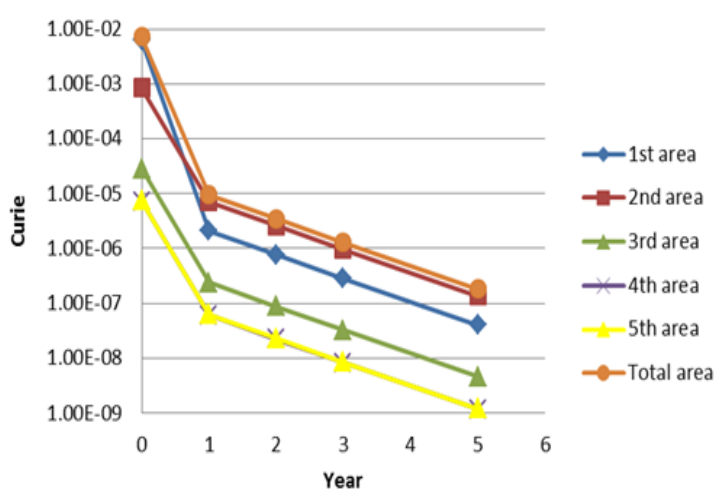

Figure 6. Radioactivity on the bottom of the reactor tank in the 1st to 5th area.

Figure 6 illustrates the radioactivity of the reactor tank bottom in each area and total radioactivity of the bottom of reactor tank. It can be seen that after 5 years decay time, the radioactivity at $4^{\text {th }}$ and $5^{\text {th }}$ area has reached on the order of $10^{-9}$, while the highest radioactivity is in the $2^{\text {nd }}$ area that is on the order of $10^{-7}$. This is because of the $2^{\text {nd }}$ area volume is larger than the $1^{\text {st }}$ area. Total radioactivity at the bottom of the reactor tank after 5 years decay time is $1.8310^{-7}$ Curie.

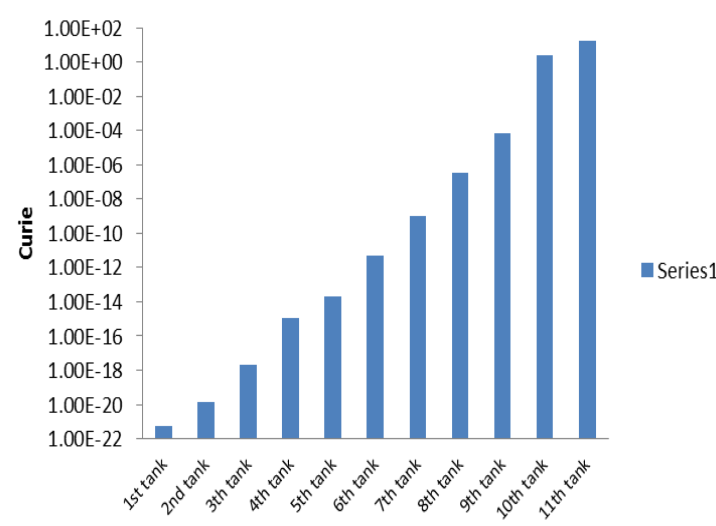

Figure 7 . The radioactivity of the reactor tank wall before decay time.

On the wall of the reactor tank, the highest radioactivity before decay are at the $11^{\text {th }}$ tank sliced that is on the order of $10^{1}$ Curie. The position of this $11^{\text {th }}$ tank is adjacent to the reactor core so that the neutron flux is the most induced.

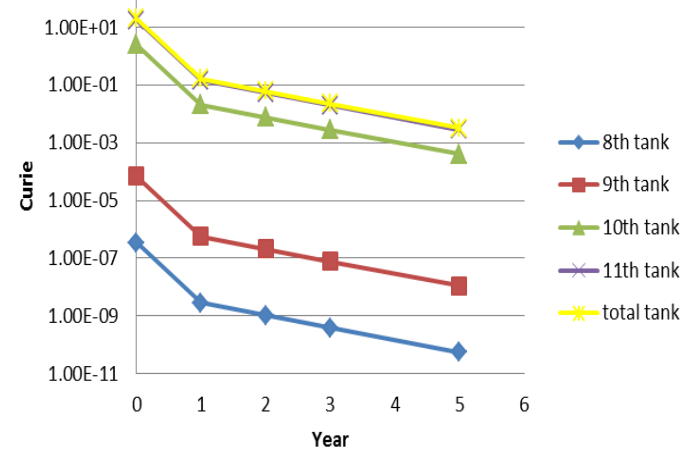

Figure 8. Radioactivity on the wall of the reactor tank in the 8th to 11th area.

In Figure 8 it can be seen that the largest tank activity after 5 years decay time 
is $2.810^{-3}$ Curie namely in the tank $11^{\text {th }}$ area, while the total radioactivity of the reactor tank wall is equal to $3.210^{-3}$ Curie. Radioactivity is derived from Zn65, Mn54 and Co60. These Nuclide has a long half-life that is 244.1 days for $Z n 65,312.2$ days for Mn54 and 5.271Years for Co60.

\section{CONCLUSION}

In this paper, we focused on the calculation of the neutron induced activity of nuclear reactor tank. The results confirm, that the most important radionuclides in the reactor tank are Zn65, Mn54 and Co60. Co60 Nuclide should get more attention because it has a very long half-life. The total radioactivity at the bottom of the reactor tank after 5 years decay time is $1.8310^{-7}$ Curie and the total radioactivity of the reactor tank wall is equal to $3.210^{-3}$ Curie.

\section{ACKNOWLEDGMENTS}

The authors would like to acknowledge the Center for Applied Nuclear Science and Technology for supporting this research using the funding of DIPA PSTNT BATAN FY 2014 and also thanks to all friend in Technophysics group for discussion.

\section{REFERENCES}

1. Nuclear Energy Regulatory Agency of Indonesia Chairman Regulation No 4/2009 on Decommissioning of Research Reactors, in Indonesian, http://www.batan.go.id/ptlr/11id/sites/def ault/files/perka-bapeten-4-2009-dekomreaktor.pdf. Downloaded 20-10-2016
2. Safety Analysis Report TRIGA 2000 Bandung Reactor, $3^{\text {rd }}$ rev, 2006

3. Bouhaddane, A., Farkas G., Calculation of induced activity in the $V$ 230 reactor, Proceedings of the 19th International Conference APCOM Applied Physics of Condensed Matter, Štrbské Pleso, Slovak Republic 2013, page. 139-144. ISBN: 978-80-2273956-6.

4. Mulyono Daryoko, Nurokhim, The estimation of radionuclide on TRIGA MARK II research reactor component using computer code ORIGEN 2, in Indonesian, Seminar Nasional Teknologi Pengelolaan Limbah IX, Gedung Graha Widya Bhakti DRN, 5 Oktober 2011, page 33-37

5. Antti Raty, Petri Kotiluoto, FIR 1 TRIGA activity inventories for decommissioning planning, Symposium on Preparation for Decommissioning, Lyon, France, February 16-18, 2016

6. M. Rahgoshay, M. Hashemi-Tilehnoee and M. Khaleghi, Calculating the Outcore Radioactivity in VVR-S Reactor after Shutdown, Indian Journal of Science and Technology, Vol 7(9), 1250-1254, September 2014

7. Kyoungho Noh, Chang Joo Hah, Radiation Source Term Analysis for Wolsong Unit 1 Using MCNP/ORIGEN2, International Journal of Recent Development in Engineering and Technology, ISSN 2347-6435(Online) Volume 4, Issue 2, February 2015

8. Evelina Ionescu, Daniela Gurau, Doru Stanga, Octavian G. Duliu, 
Decommissioning of the VVR-S

Research Reactor - Radiological

Characterization of the Reactor Block,

Romanian Reports in Physics, Vol. 64

No. 2, 2012, Page 387-398

9. João Paulo Vieira, Maria A. Fortini, Claubia Pereira and, Antonella L. Costa, Development of a Friendly Interface for ORIGEN 2.1 Code Using Matlab Software, International Nuclear Atlantic Conference - INAC 2011, Belo Horizonte,MG, Brazil, October 24-28, 2011

10. Edi Triyono B.S., Syarip, Computational Analysis of Minor Actinide Waste Transmutation Preliminary Study of-ADS Based on Kartini Reactor, in Indonesian, Prosiding Seminar Nasional Teknologi Pengelolaan Limbah IX, Pusat Teknologi Limbah Radioaktif-BATAN, Fakultas Teknik Universitas Sultan Ageng Tirtayasa ISSN 1410-6086, 30 desember 2011, page 21-31

11. R.G. Abrefah, S.A. Birikorang, B.J.B. Nyarko, J.J. Fletcher and E.H.K. Akaho, Fuel Depletion Studies of Ghana Research Reactor-1 using ORIGEN2:
Part 2 -Analyses of Photon source density, Elixir Nuclear \& Radiation Phys. 53 (2012) 11988-11991

12. Gabriele Hampel, Friedemann Scheller, Wolfgang Bernnat, Gerhard Pfister, Uwe Klaus, Erich Gerhards, Calculation of the Activity Inventory for the TRIGA Reactor at the Medical University of Hannover (MHH) in Preparation for Dismantling the Facility, WM'02 Conference, February 24-28, 2002, Tucson, AZ

13. Sudjatmi K.A., P.I. Yazid, Reinaldy Nazar, Fatchatul B., Neutron Flux Distribution in TRIGA Bandung Reactor Tank, in Indonesian, Seminar Nasional Sains dan Teknologi Nuklir 2015, Aula Timur ITB - Bandung, 3 Desember 2015, page 174-177

14. ORIGEN2 - RSIC Computer Code Collection, National Laboratory, Oak Ridge, Tennessee, September 1990.

15. Menno Blaauw, The k0-Consistent IRI Gamma-ray Catalogue for Instrumental Neutron Activation Analysis, Interfacultair Reactor Instituut van de Technische Universiteit Delft 1996 